\title{
Knee and ankle disorders during functional gait in mucopolysaccharidosis type VI
}

\author{
Distúrbios articulares de joelho e tornozelo durante a marcha funcional na \\ mucopolissacaridose tipo VI
}

Trastornos de la rodilla y el tobillo durante la marcha funcional en mucopolisacaridosis tipo VI

Bárbara Bernardo Figueirêdo', Paulo Magalhães², Breno Azevedo³, Maria Lucila Cavalcanti ${ }^{4}$, Maria Emília Melo ${ }^{5}$, Cinthia Vasconcelos ${ }^{6}$

\begin{abstract}
I To evaluate knee and ankle disorders during functional gait assessment in individuals with Mucopolysaccharidosis type VI (MPS VI). 19 subjects were included in this cross-sectional study and allocated in three groups according to age: Children Group ( $n=11)$; Adolescent Group ( $n=4)$; and Adult Group $(n=4)$. Subphases of one gait cycle were analyzed: Initial contact; Medium support, and Pre-Balance. All volunteers with MPS VI presented greater knee and ankle flexion angles, in all gait subphases, when compared to the normal values defined by literature $(p<0.05)$. Initial contact subphase: knee flexion angle ranging from

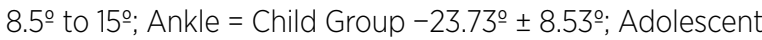
Group $=-25^{\circ} \pm 11.22^{\circ}$; Adult Group $=-27.75^{\circ} \pm 3.3^{\circ}$. Medium support subphase: Knee = Child Group 19.64 $\pm 10.47^{\circ}$; Adolescent Group 16.75 $\pm 10.34^{\circ}$; Adult Group $=21.25^{\circ} \pm 12.84^{\circ}$. Ankle $=$ Child Group $-18.82^{\circ} \pm 8.91^{\circ} \pm 8.53^{\circ}$; Adolescent Group $=$ $-16.5^{\circ} \pm 9.33^{\circ}$; Adult Group $=-22.25^{\circ} \pm 4.19 \circ$. Pre-Balance subphase: Knee $=$ Child Group 22.72 $\pm 13.49^{\circ}$; Adolescent Group 21.25 \pm 7.97우 Adult Group $=27 \circ \pm 16.27 \circ$. Ankle $=$ Child Group -15 $\pm 9.76^{\circ}$; Adolescent Group $=-15.75^{\circ} \pm 5.31^{\circ}$; Adult Group $=-14.75^{\circ} \pm 3.86^{\circ}$. In this study, MPS VI individuals presented hyperflexion of knee and ankle as the main joint disorders during functional gait, regardless of age.

Keywords | Mucopolysaccharidosis Vl; Gait Analysis; Range of Motion, Articular.
\end{abstract}

RESUMO | O objetivo deste estudo foi avaliar distúrbios articulares de joelho e tornozelo durante a marcha funcional na Mucopolissacaridose tipo VI (MPS VI). 19 indivíduos foram incluídos neste estudo transversal e alocados em três grupos de acordo com a idade: Grupo Crianças ( $n=11)$; Grupo Adolescentes ( $n=4)$; e Grupo Adultos $(n=4)$. Foram analisadas as subfases de um ciclo da marcha: contato inicial; apoio médio e pré-balanço. Todos os voluntários com a MPS VI apresentaram maiores ângulos de flexão do joelho e tornozelo, em todas as subfases da marcha, quando comparados aos valores normais definidos pela literatura $(p<0,05)$. Subfase contato inicial: ângulo de flexão do joelho variando de 8,5 a 15ㅜㅜ Tornozelo = Grupo Criança $-23,73^{\circ} \pm 8,53^{\circ}$; Grupo Adolescente $=-25^{\circ}$ \pm 11,22우 Grupo Adulto $=-27,75^{\circ} \pm 3,3 \div$. Subfase apoio médio: Joelho = Grupo Criança 19,64ํㅗ 10,47우 ;rupo Adolescente $16,75^{\circ} \pm 10,34^{\circ}$; Grupo Adulto $=21,25^{\circ} \pm$

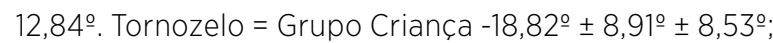
Grupo Adolescente $=-16,5^{\circ} \pm$ 9,33; Grupo Adulto $=$ $-22,25^{\circ} \pm$ 4,19․ Subfase pré-balanço: Joelho = Grupo

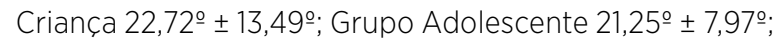
Grupo Adulto $=27^{\circ} \pm 16,27^{\circ}$. Tornozelo $=$ Grupo Criança $=$ $-15^{\circ} \pm$ 9,76우 ; Grupo Adolescente $=-15,75^{\circ} \pm$ 5,31; Grupo Adulto $=-14,75^{\circ} \pm 3,86^{\circ}$. Neste estudo, os indivíduos com MPS VI apresentaram hiperflexão do joelho e tornozelo como principais distúrbios articulares durante a marcha funcional, independentemente da idade.

Descritores | Mucopolissacaridose VI; Análise da Marcha; Amplitude de Movimento Articular.

\footnotetext{
'Universidade Federal de Pernambuco (UFPE) - Recife (PE), Brazil. E-mail: barbara_bernardo@hotmail.com. Orcid: 0000-0002-4949-6268 2Universidade de Pernambuco (UPE) - Petrolina (PE), Brazil. E-mail: paulof.magalhaes@upe.br. Orcid: 0000-0002-2224-9291 3Universidade de Pernambuco (UPE) - Petrolina (PE), Brazil. E-mail: brenodiazev@gmail.com. Orcid: 0000-0003-4917-8726 ${ }^{4}$ Universidade Federal de Pernambuco (UFPE) - Recife (PE), Brazil. E-mail: marialucila_852@hotmail.com. Orcid: 0000-0001-9957-6656 5Universidade de Pernambuco (UPE) - Petrolina (PE), Brazil. E-mail: emilia.ferraz@upe.br. Orcid: 0000-0001-9924-0466 ${ }^{6}$ Universidade Federal de Pernambuco (UFPE) - Recife (PE), Brazil. E-mail: cinthiavasconcelosfisio@gmail.com. Orcid: 0000-0003-0604-7697
} 
RESUMEN | El objetivo de este estudio fue evaluar los trastornos de la articulación de la rodilla y el tobillo durante la marcha funcional en mucopolisacaridosis tipo VI (MPS VI). En este estudio transversal participaron 19 personas, las cuales se asignaron a tres grupos según la edad: Grupo Niños ( $n=11)$; Grupo Adolescente $(n=4)$; y Grupo Adulto $(n=4)$. Se analizaron las subfases de un ciclo de marcha: contacto inicial; soporte mediano y balance previo. Todos los voluntarios con MPS VI tuvieron mayores ángulos de flexión de rodilla y tobillo en todas las subfases de la marcha en comparación con los valores normales definidos por la literatura $(p<0,05)$. En la subfase de contacto inicial: ángulo de flexión de

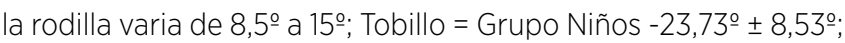
Grupo Adolescente $=-25^{\circ} \pm 11,22^{\circ}$; Grupo Adulto $=-27,75^{\circ} \pm 3,3^{\circ}$.
En la subfase de soporte mediano: Rodilla $=$ Grupo Niños 19,64노

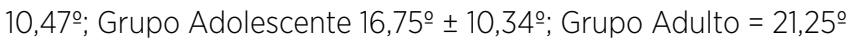
\pm 12,84․ Tobillo $=$ Grupo Niños $-18,82^{\circ} \pm$ 8,91ํㅗ 8,53우 ;rupo Adolescente $=-16,5^{\circ} \pm 9,33^{\circ}$; Grupo Adulto $=-22,25^{\circ} \pm 4,19 ․$. En la subfase de balance previo: Rodilla $=$ Grupo Niños 22,72 $\pm 13,49$; Grupo Adolescente 21,25 \pm 7,97우 ; Grupo Adulto $=27^{\circ} \pm 16,27^{\circ}$. Tobillo = Grupo Niños = -15ะ \pm 9,76ㅇ; Grupo Adolescente $=-15,75^{\circ} \pm$ 5,31ㅜ; Grupo Adulto = -14,75 $\pm 3,86^{\circ}$. En este estudio, los individuos con MPS VI presentaron hiperflexión de rodilla y tobillo como los principales trastornos articulares durante la marcha funcional independiente de la edad.

Palabras clave / Mucopolisacaridosis VI; Análisis de Marcha; Rango de Movimiento Articular.

\section{INTRODUCTION}

Mucopolysaccharidosis type VI (MPS VI), also known as Maroteaux-Lamy syndrome, is characterized by progressive autosomal recessive lysosomal storage deficiency with multisystemic involvement ${ }^{1}$. The main cause of MPS VI is the decreased enzymes $\mathrm{N}$-acetylgalactosamine 4-sulfatase or arylsulfatase B (ARSB) - which is directly correlated with the degradation of glycosaminoglycans (GAGs) dermatan sulfate and chondroitin 4-sulfate. Impairments in enzymatic activity lead to accumulation of partially degraded GAG in different tissues and organs ${ }^{2}$.

MPS VI shares many clinical features but has varying degrees of severity and it can severely impair the function of the musculoskeletal system. Walking disorders are the main routine medical complaints and they are considered by this group as one of the biggest causes of functional disabilities ${ }^{3}$. Joint deformities found in MPS type VI hinder gait and balance, causing greater functional dependence in activities of daily living ${ }^{1}$.

Physical therapy has a significant role in the treatment of musculoskeletal disorders in patients with MPS VI, the physical therapist acts directly on muscle and joint disorders, preventing falls, functional decline, and consequently improving quality of life $\mathrm{f}^{4}$. Therefore, a good evaluation is necessary to better understand pathological conditions related to MPS functional disorders, thus enabling better therapeutic interventions $\mathrm{s}^{3,5}$.

This study evaluates knee and ankle disorders during functional gait assessment in individuals with Mucopolysaccharidosis type VI (MPS VI).

\section{METHODOLOGY}

This cross-sectional study was carried out in the Center for the Treatment of Inborn Errors of Metabolism of the Instituto de Medicina Integral Professor Fernando Figueira (CETREIM-IMIP), Recife, Pernambuco, Brazil, under the approval of the Human Ethics Committee of IMIP ( $n^{\circ}$ 4713-15). The sample consisted of patients with clinical diagnosis of MPS VI, both sexes, aged from three to 39 years, with independent gait and undergoing enzyme replacement therapy.

Exclusion criteria were: patients with cognitive impairment or neurological disorders; recent surgical procedures (less than 24 months) in the trunk or lower limbs; hearing and / or visual disorders that could compromise the achievement evaluations.

The study included 21 patients, however there was one (1) loss (non-collaborative child) and one (1) discontinuity of the study (it was not possible to perform the recording properly due to the difficulty in understanding the instructional commands). Thus, the final sample for gait analysis consisted of 19 patients allocated into three groups, according to age, following the classification of the World Health Organization (WHO): Child Group (0-9 years), Adolescent Group (10-19 years), and Adult Group (above 20). Child Group was composed of 11 volunteers and the Adolescent and Adult Groups, by four participants each.

Initially, sociodemographic and clinic-biological information was collected from a form created by the authors, containing information such as age, sex, weight, height, Body Mass Index (BMI), time of diagnosis, 
whether or not physical therapy was performed, and the presence of pain in lower limb.

Gait analysis was carried out with videos recorded in the sagittal plane in a large room. For filming, a digital photo camera (Sony ${ }^{\circledR}$ DSC-HX60 of 20.4 megapixels) was used, positioned on a tripod of the SUNPAK ${ }^{\circledR} 5200 \mathrm{D}$ brand. The tripod was positioned - in relation to height and distance - in order to fit the patient in the machine's display to capture the image.

The participants were encouraged to walk a round-trip route three times, making an average of seven walking cycles on each route. The right and left profiles were filmed in order to obtain the moments of the Support Phase subphases proposed to be analyzed in this study: Initial Contact (IC), Medium Support (MS), and Pre-Balance (PB), of both lower limbs.

All evaluations were performed with patients dressed in light clothing, in order to allow the observation of the five markers placed on the anatomical points of the lower limbs (head of the $V$ metatarsus, below the central point of the lateral malleolus, head of the fibula, lateral condyle of the femur, and greater trochanter of the femur). These marks allowed to measure the angles of the movements of the sagittal plane of the knee joint (flexion and extension) and of the ankle (plantar flexion and dorsiflexion).

The entire route was recorded, but the capture of the images used in this study was made at the intermediate point of the gait, that is, approximately in the three intermediate cycles of the recorded gait (without the interference of acceleration and deceleration of the cycle). The researchers captured three specific images, which were related to the first moment of each sub-phase (IC, MS, and PB), of both members.

All images were analyzed with the Software Tracker, a free access program used to analyze the angulations of the joints of the lower limbs ${ }^{5}$. For data analysis, all information obtained from the forms was individually entered, as well as with the Software Tracker, in a specific database created in Microsoft EXCEL $2007{ }^{\circledR}$. These data were revised after typing was completed, in order to correct any errors.

With the statistical program SPSS $18{ }^{\circledR}$, the Shapiro Wilk Test was used to analyze data normality, verifying that the data had no normal distribution. Thus, with the Wilcoxon non-parametric test, continuous variables related to joint angulations were analyzed, considering a $p<0.05$ level of statistical significance.

The analyses related to the comparison of the angulations averages of the three groups with the values of normality of angulations provided by the literature ${ }^{6}$. Furthermore, averages comparisons between groups were performed in a descriptive way, using the graphical representation. For this comparison and obtaining the averages, only one angular value was used in each subphase, without distinction between members, adopting the member that remains in the support phase when the participant starts walking.

It is understood that the gait cycle is the sequence of support and advance of a single limb, being divided into two phases: the support phase - in which the foot is in contact with the ground - and the swing phase - in which the foot is off the ground to move the limb ${ }^{7}$.

Based on Perry ${ }^{8}$, as the IC captured, the first moment was considered the contact between foot and ground. For MS - which is defined as the period between the departure of the contralateral foot from the ground (swing phase of the lower limb not analyzed) until the moment when the body weight is transferred to the anterior region of the foot in support - was considered the moment when the contralateral foot leaves. For the sub-phase of PB which is understood from the beginning of the initial contact of the opposite foot to the detachment of the supported foot - the initial contact of the opposite foot was considered.

As normal values for angulations in each sub-phase, IC was considered as $5^{\circ}$ of flexion in the knee joint and $5^{\circ}$ of plantar flexion $\left(-5^{\circ}\right)$ for the ankle. For MS, $3^{\circ}$ and $5^{\circ}$ of dorsiflexion of the ankle was considered knee flexion. For $\mathrm{PB}, 10^{\circ}$ of knee flexion and $8^{\circ}$ of dorsiflexion for the ankle joint ${ }^{6}$. Understanding the knee and ankle joint angles in patients with MPS VI during gait may provide new significant data to better target the maintenance of the range of motion necessary for harmonic gait, gait rehabilitation, and preventive treatment in this group.

Only two examiners performed the evaluations: one responsible for capturing the video image of the gait at the time of collection and the other responsible for placing the marks on the anatomical points of the patients'body before the evaluation. Intra- and inter-examiner tests were not performed, as the evaluators were always the same and did not change their function during collection.

\section{RESULTS}

Among the sociodemographic and clinical characteristics of patients with MPS type VI, eight are 
female and 11 are male, and the mean age of the Child Group was 5.64 years ( \pm 1.86 ), the Adolescent Group was 13.25 years $( \pm 2.87)$, and the Adult Group was 32.75 years $( \pm 8.26)$. Only six participants underwent physical therapy treatment and, regarding the existence of pain in the lower limbs, most patients in the three groups had complaints of this nature (Table 1 ).

Table 1. Sociodemographic and clinical features of patients with Mucopolysaccharidosis type $\mathrm{VI}$

\begin{tabular}{lrrr}
\multicolumn{1}{c}{ Characteristic } & $\begin{array}{c}\text { Child } \\
(\mathrm{n}=11)\end{array}$ & $\begin{array}{c}\text { Adolescents } \\
(\mathrm{n}=4)\end{array}$ & $\begin{array}{c}\text { Adults } \\
(\mathrm{n}=4)\end{array}$ \\
\hline Female/Male* & $5 / 6$ & $2 / 2$ & $1 / 3$ \\
Age (years) & $5.64 \pm 1.86$ & $13.25 \pm 2.87$ & $32.75 \pm 8.26$ \\
Weight (Kg) & $17.43 \pm 4.25$ & $28.85 \pm 13.97$ & $46.45 \pm 15.87$ \\
Height (m) & $0.99 \pm 0.09$ & $1.11 \pm 0.11$ & $1.36 \pm 0.21$ \\
IMC** (Kg/m²) & $17.47 \pm 1.92$ & $22.3 \pm 5.92$ & $24.48 \pm 1.96$ \\
Diagnostic Time (months) & $51.64 \pm 16.19$ & $138.5 \pm 37.39$ & $279 \pm 64.53$ \\
Physical therapeutic & $1 / 10$ & $3 / 1$ & $2 / 2$ \\
Treatment (S/N)*** & & & \\
Pain in the MMII*** (S/N) & $8 / 3$ & $4 / 0$ & $4 / 0$ \\
- Knee and Leg (\%) & 25 & 75 & 50 \\
- Ankle and Foot (\%) & 37.5 & 25 & 25 \\
- Hip (\%) & 12.5 & 0 & 25 \\
- All joints (\%) & 25 & 25 & 25
\end{tabular}

*F: female / M: male; ${ }^{* *}$ BMI: Body Mass Index; ${ }^{* * *}$ Y: YES / N: NO; **** MMII: lower limbs.

In the descriptive analysis of the means of knee and ankle angles - in all three gait sub-phases of the three groups - it was verified that the volunteers have higher angles of knee flexion and plantar flexion, respectively, when compared to the normal values defined in the literature. This difference is more evident in the Adult Group (Figures 1 and 2). In the IC phase - whose expected knee angle is $5^{\circ}$ of flexion - the Child Group presented $12.36^{\circ} \pm 6.8^{\circ}$, the Adolescent Group presented $8.5^{\circ} \pm 7.42^{\circ}$ and the Adult Group recorded $15^{\circ} \pm 10.64^{\circ}$ (Figure 1 ).

In the analysis of the ankle, whose expected normality was $5^{\circ}$ of plantar flexion $\left(-5^{\circ}\right)$, the following results were obtained: Child Group presented $-23.73^{\circ}$ $\pm 8.53^{\circ}$, the Adolescent Group presented $-25^{\circ} \pm 11.22^{\circ}$ and in the Adult Group $-27.75^{\circ} \pm 3.3^{\circ}$ was recorded (Figure 2).

In the medium support - considering the angulation of normality for this sub-phase $-3^{\circ}$ of knee flexion and $5^{\circ}$ of ankle dorsiflexion. In this study, the knees showed an increase in flexion angle, with the following mean values: Child Group presented $19.64^{\circ} \pm 10.47^{\circ}$, the Adolescent Group presented $16.75^{\circ} \pm 10.34^{\circ}$, and in the Adult Group it was recorded $21.25^{\circ} \pm 12.84^{\circ}$ (Figure 1 ).

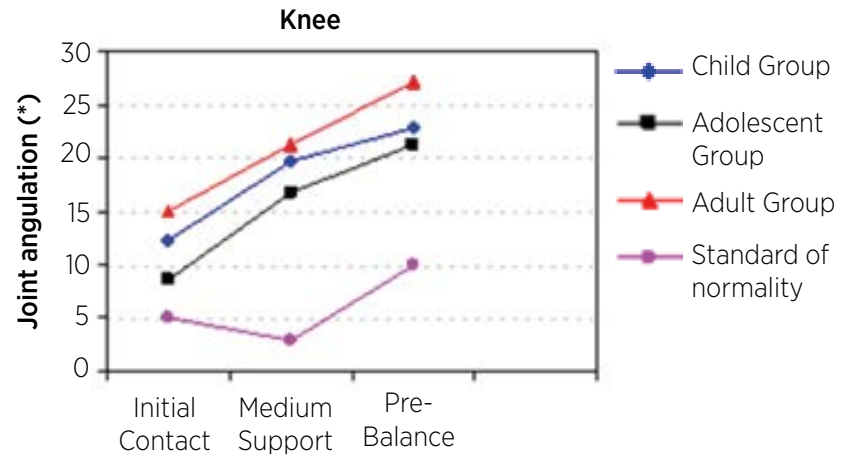

Figure 1. Graph of the mean angular values obtained from the knee joint in three sub-phases of gait, from the support phase, in patients with type VI Mucopolysaccharidosis

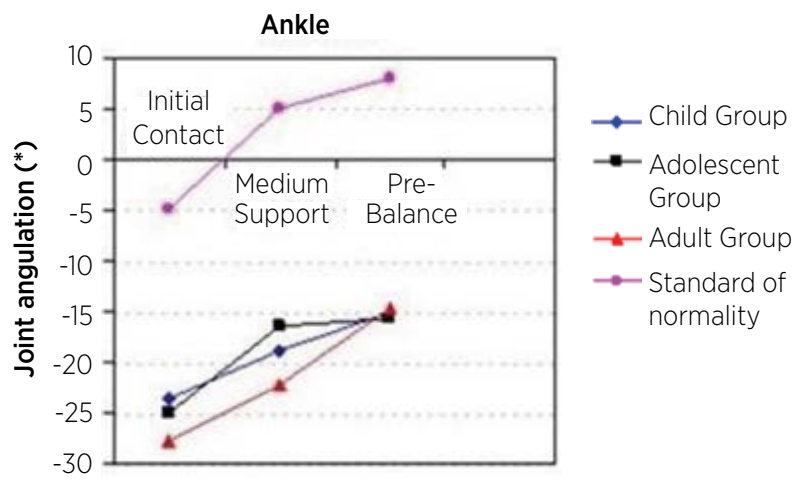

Figure 2. Graph of the mean angular values obtained from the Ankle joint in three stages of gait, from the support phase, in patients with Mucopolysaccharidosis type VI

The ankle angles were as follows: $-18.82^{\circ} \pm 8.91^{\circ}$ for the Child Group, $-16.5^{\circ} \pm 9.33^{\circ}$ for the Adolescent Group, and $-22.25^{\circ} \pm 4.19^{\circ}$ for the Adult Group (Figure 2). In the $\mathrm{PB}$ sub-phase, angular changes were also recorded in the three groups, emphasizing that the normality values were $10^{\circ}$ of knee flexion, but in the Child Group there was $22.72^{\circ} \pm 13.49^{\circ}$ of flexion, in the Adolescent Group 21.25 $\pm 7.97^{\circ}$, and in the Adult Group $27^{\circ} \pm 16.27^{\circ}$ (Figure 1).

In the ankle joint, normality is represented by $8^{\circ}$ of dorsiflexion, but in the three groups studied, in this joint occurs the plantar flexion movement, distributed as follows: Child Group $-15^{\circ} \pm 9.76^{\circ}$, Adolescent Group $-15.75^{\circ} \pm$ $5.31^{\circ}$, and Adult Group $-14.75^{\circ} \pm 3.86^{\circ}$ (Figure 2).

\section{DISCUSSION}

The gait of patients with type VI MPS shows an increase in the knee joint flexion angulation during the initial contact (IC), medium support (MS), and prebalance $(\mathrm{PB})$ sub-phases, of the support phase, when 
compared to the value referenced by the literature for this articulation. In relation to the ankle joint, patients with this disease remain in plantar flexion in the three sub-phases (IC, MS, and PB), emphasizing that in normal parameters there should only have been plantar flexion in the IC, as in the MS and in PB, this joint should perform dorsiflexion. Studies aimed to analyze normal gait have shown that during IC the knee is progressing to flexion and in MS it returns to an extension, decreasing the degree of flexion ${ }^{4,8}$.

Analyzing the angular records of knee flexion, in the three sub-phases, it appears that the greatest amplitudes are in the Adult Group, followed by the Child Group, and finally by the Adolescent Group. This reality is not compatible with what is expected when the range of articulation is related to the patients' age, the time of disease diagnosis, or the existence of joint pain in the lower limbs in these groups. In other words, it was expected that the greater the angle and the distance from the angle considered normal, the greater these numerical variables, such as age, would be.

According to the angles of the ankle joint - during gait in this study - it was found that it remained in plantar flexion, with decreasing amplitude as the support phase occurred, but the dorsiflexion movement was not registered in none of the three groups. Notably, the graphic record of the range of motion in the Adult and Child Groups was similar, and again, the Adolescent Group had a different distribution than the other two groups. The plantar flexion movement in the gait support phase of these patients can be justified by the existence of joint contractures and stiffness, either by the accumulation of GAGs in the joints, or by the likely muscle shortening ${ }^{9}$.

In patients with MPS - since the first years of life there is a restriction in the range of motion, especially in the knees, making the patients assume a posture with bent knees. Some authors found knee joint impairments unrelated to age, thus explaining the fact that the adolescents in our study did not have greater flexion ranges when compared to children ${ }^{10-12}$.

Another point that must be considered is the radiological findings that have been reported in some studies of MRI in patients with MPS type VI. Compression of the spinal cord - especially in the cervical region - is a serious complication of those patients and usually arises from stenosis of the spinal canal, secondary to malformations of the spine and base of the skull, as well as the accumulation of GAG in the soft tissues around the spinal cord, resulting in myelopathy or myelomalacia ${ }^{13,14}$.

Compression of the cervical cord affects patients aged one year and includes clinical signs such as weakness, paresthesia, difficulty in walking, and abnormal evoked potentials ${ }^{13,14}$. Although no clinical investigations have been carried out on patients in this regard, it may be a factor that could justify the findings of the current study regarding gait changes.

This descriptive analysis of the gait sub-phases - in the support phase - comparing the groups that were outlined in this study, according to the age group, it is possible to see that the pattern of maturity in the angular variations of joints in gait is well established between three and four years of age ${ }^{15}$ and, second Rose and Gamble ${ }^{9}$, there are few changes in children after three years of age.

Thus, as the average age in the Child Group was 5.64 years $( \pm 1.86)$, and their minimum age was three years, the existence of toddlers - which are the individuals who have not reached independence in gait and who are still in a moment of transition towards the acquisition of a mature gait pattern, characteristic of adults ${ }^{8}$.

The relevance of this study is due to the fact that the angular measurements of the knee and ankle joints are related to the functionality of patients with MPS type VI during gait. Knowing that, in typical gait, the sequence of movements depends on joint mobility and muscle action - thus providing less energy consumption ${ }^{16}$ - this study collaborates with the identification of the angular changes of these patients in different age groups.

That gait analysis in patients generates quantitative parameters that can be used to monitor the effectiveness of the therapeutic interventions. Knee mobility and stability, for example, are the main factors in normal gait pattern and it is a basic determinant of limb stability during support ${ }^{7}$.

There are reports that the best way to assess the severity of the disease is with the patient's functionality. To correlate the severity of the disease and the patient's functional impairment, joint angulation measurement has been used ${ }^{2}$. In patients with MPS VI, the goniometer has been used as an instrument for this measurement ${ }^{5,9}$. However, this method has been shown to be insensitive when the measurement is related to functional positions, since it is performed only in a static way ${ }^{17}$ and, rarely, dynamically measures the performance of a function.

Few studies on gait have been performed in patients with MPS, but the one carried out by Matos et al. ${ }^{3}$ analyzed the energy expenditure of walking in individuals with MPS 
$(\mathrm{n}=19)$ and in asymptomatic individuals ( $\mathrm{n}=19)$, verifying that individuals with MPS had a twice as high expenditure compared to asymptomatic individuals and greater time to perform the walk. The authors stated that this finding reflects the motor limitation of this population ${ }^{3}$.

Therefore, based on the findings of Matos et al. ${ }^{3}$, it is assumed that the patients evaluated in our study, who have MPS VI and who had angular changes in the range of motion of the knees and ankles during the support phase, should present an increase in energy expenditure to perform the gait due to the necessary compensations throughout the body to maintain this functionality.

As for the identification of sociodemographic profile of patients with Mucopolysaccharidosis type VI, from the Center for the Treatment of Inborn Errors of Metabolism at the Instituto de Medicina Integral Professor Fernando Figueira (CETREIM-IMIP), involved in this study, it appears that there was a similarity with the average age group of the observational study carried out by Cardoso-Santos ${ }^{11}$ involving 28 patients with MPS VI, whose mean age was 8.1 years $( \pm 2.9)$.

In the study of Matos et al. ${ }^{3}$, the average age was 11.32 years $( \pm 5.95)$. Regarding gender, studies show a higher prevalence of males, in agreement with our study ${ }^{3,10}$. In this study, 13 patients $(68.42 \%)$ were diagnosed before the age of three. The diagnosis in this population is usually given between one and three years, due to the fact that it is the period of onset of the first signs of the disease ${ }^{18-21}$.

The Guideline published by Giugliani ${ }^{20}$ described the height deficit as one of the signs of MPS type VI, reporting a characteristic of short throne and thoracolumbar hump. The height deficit of patients found in this study can be justified by the records of the aforementioned Guideline, but making the association of these height changes with the severity of the disease was not possible in this study, according to CETREIM-IMIP professionals, due to the genetic mutation (State of Pernambuco) that makes this type of diagnosis difficult.

Clinically, in this study, the presence of pain in the lower limbs was observed in $72 \%$ of the patients in the Child Group and in all participants of the Adolescent and Adult Groups. These findings corroborate the study by Medeiros et al. ${ }^{18}$ which involved 13 patients with MPS VI, who reported joint pain, with $76.9 \%$ of those evaluated reporting it in the upper limbs. No studies were found reporting the presence of pain, specifically, in the lower limbs.

Despite the high frequency of painful complaints observed in the participants of this study, only six individuals underwent physical therapy treatment, with frequency of once a week, being a child, three adolescents, and two adults. The authors assume that the failure to perform the treatment is due to the difficulty of patients moving to the rehabilitation service, since most patients involved in our study live in inland cities. Thus, there are difficulties regarding access and continuity of physical therapy treatment and, possibly, an aggravation of the disease.

The scarcity of studies about gait biomechanics in individuals with MPS type VI justify the need for more robust research in order to provide further clarification about the relationship of impairments, disabilities, and gait disorders with biological variables in this specific population, as well as functional and even impact on their quality of life, which could not be analyzed in our study.

\section{CONCLUSION}

In this study, MPS VI individuals presented hyperflexion of knee and Ankle plantarflexion in the sub-phases of initial contact, medium , and pre-balance support, as the main joint disorders during functional gait, regardless of age. These joint disorders seem to get worse with aging.

\section{REFERENCES}

1. Akyol MU, Alden TD, Amartino H, Ashworth J, Belani K, Berger $\mathrm{Kl}$, et al. Recommendations for the management of MPS VI: systematic evidence- and consensus-based guidance. Orphanet J Rare Dis. 2019;14:118-39. doi: 10.1186/s13023-019-1080-y

2. Harmatz P, Shediac R. Mucopolysaccharidosis VI: pathophysiology, diagnosis and treatment. Front Biosci. 2017;1;22:385-406. doi: 10.2741/4490

3. Matos MA, Prado A, Schenkel G, Barreto R, Acosta AX. Gasto energético na marcha em pacientes com mucopolissacaridose. Acta Ortop Bras. 2013;21(2):116-9. doi: 10.1590/S1413-78522013000200009

4. Figueirêdo BBRS, Magalhães PAF, Andrade LBD, Patrícia B, Duarte MCMB. Nível de independência, capacidade funcional e força muscular respiratória de pacientes com mucopolissacaridose tipo VI no Nordeste do Brasil. Rev Bras Saude Mater Infant. 2018;18(1):83-92. doi: 10.1590/1806-93042018000100004

5. Morais Filho MC, Reis RAD, Kawamura CM. Avaliação do padrão de movimento dos joelhos e tornozelos durante a maturação da marcha normal. Acta Ortop Bras. 2020;18(1):23-25. doi: 10.1590/S1413-78522010000100004

6. Calloni, GJ. A Física dos movimentos analisada a partir de vídeos do cotidiano do aluno: Uma proposta para oitava série [dissertation]. Porto Alegre: Universidade Federal do Rio Grande do Sul; 2010 [cited 2021 Jan 21]. Available from: http://hdl.handle.net/10183/28179 
7. Kadaba, MP, Ramakrishnan HK, Wootten ME. Measurement of lower extremity kinematics during level walking. J Orthop Res. 1990;8(3):383-92. doi: 10.1002/jor.1100080310

8. Perry J, editor. Análise de Marcha. São Paulo: Manole; 2005.

9. Rose J, Gamble JG, editors. Marcha Humana. São Paulo: Premier; 1998.

10. Jurecka A, Zakharova E, Malinova V, Voskoboeva E, TylkiSzymańska A. Attenuated osteoarticular phenotype of type VI mucopolysaccharidosis: A report of four patients and a review of the literature. Clin Rheumatol. 2014;33:725-31. doi: 10.1007/ s10067-013-2423-z

11. Cardoso-Santos A, Azevedo ACMM, Simone F, Burin MG, Giugliani R, Schwartz IVD. Mucopolysaccharidosis type VI (Maroteaux-Lamy syndrome): assessment of joint mobility and grip and pinch strength. J Pediatr. 2008;84(2):130-5. doi: 10.1590/S0021-75572008000200007

12. Azevedo AC, Schwartz IV, Kalakun L, Brustolin S, Burin MG, Beheregaray AP. Clinical and biochemical study of 28 patients with mucopolysaccharidosis type VI. Clin Genet. 2004;66:20813. doi: 10.1111/j.1399-0004.2004.00277.x

13. Valayannopoulos $V$, Nicely $H$, Harmatz P, Turbeville A. Mucopolysaccharidosis VI. Orphanet J Rare Dis 2010;5(5):120. doi: 10.1186/1750-1172-5-5

14. Bulut E, Pektas E, Sivri HS, Bilginer B, Umaroglu MM, Ozgen B. Evaluation of spinal involvement in children with mucopolysaccharidosis VI: the role of MRI. Br J Radiol. 2018;91(1085):20170744. doi: 10.1259/bjr.20170744
15. Solank GA, Sun PP, Martin KW, Hendriksz CJ, Guffon CLN, Hung A et al. Cervical cord compression in mucopolysaccharidosis VI (MPS VI): Findings from the MPS VI Clinical Surveillance Program (CSP). Mol Genet Metabol. 2016;118:310-8. doi: 10.1016/j. ymgme.2016.06.001

16. Doriot N, Chèze L. A three-dimensional kinematic and dynamic study of the lower limb during the stance phase of gait using an homogeneous matrix approach. IEEE Trans Biomed Eng. 2004;51(1):21-7. doi: 10.1109/TBME.2003.820357

17. Iwabe C, Diz MA, Barudy DP. Análise cinemática da marcha em indivíduos com Acidente Vascular Encefálico. Rev Neurocienc. 2008;16(4):292-6. doi: 10.34024/rnc.2008.v16.8618

18. Medeiros JNS, Silva BBR, Queiroz DR, Cattuzzo MT, Soares KMS. Avaliação da força de preensão e amplitude de movimentos dos membros superiores em pacientes com mucopolissacaridose VI. Acta Fisiatr. 2015;22(2):60-4. doi: 10.5935/0104-7795.20150013

19. Suarez-Guerrero JL, Higuera JP, Arias JSF, Contreras-García GA. Mucopolisacaridosis: características clínicas, diagnóstico y de manejo. Rev Chil Pediatr. 2016;87(4):295-304. doi: 10.1016/j. rchipe.2015.10.004

20. Giugliani R, Federhen A, Rojas MVM; Vieira TA; Artigalás O, Pinto, LLC, et al. Terapia de reposição enzimática para as mucopolissacaridoses I, II e VI: recomendações de um grupo de especialistas brasileiros. Rev Assoc Med Bras. 2010;56:257-77. doi: 10.1590/S0104 42302010000300009

21. Iwabe CR, Frezzato RC, Nogueira AN. Evolução motora de paciente com mucopolissacaridose tipo 1. Rev Paul Pediatra. 2010;28(3):372-5. doi: 10.1590/S0103-05822010000300018 